\title{
In Vitro Protein Digestibility and Fermentability of Mulberry (Morus alba)- Leucaena Foliage Mixed Feed
}

\author{
Yulistiani $\mathrm{D}^{1}$, Jelan $\mathrm{ZA}^{2}$, Liang $\mathrm{JB}^{3}$ \\ ${ }^{1}$ Indonesian Research Institute for Animal Production, PO Box 221 Bogor 16002, Indonesia \\ ${ }^{2}$ Department of Animal Science, Faculty of Agriculture, Universiti Putra Malaysia, Serdang, Selangor 43400, Malaysia \\ ${ }^{3}$ Institute of Tropical Agriculture, Universiti Putra Malaysia, Serdang, Selangor 43400, Malaysia \\ E-mail: dwiyulistiani@yahoo.com
}

(received 22-12-2015; revised 27-01-2016; 16-02-2015)

\begin{abstract}
ABSTRAK
Yulistiani D, Jelan ZA, Liang JB. 2016. Kecernaan protein in vitro dan fermentabilitas pakan campuran hijauan murbei dan leucaena. JITV 21(1): 9-18. DOI: http://dx.doi.org/10.14334/jitv.v21i1.1352

Penelitian dilakukan untuk mengevaluasi pengaruh campuran hijuan murbei dengan leucaena terhadap kecernaan protein dan produksi VFA (asam lemak volatile) yang diukur secara in vitro produksi gas. Hijauan murbei dicampur dengan dua varietas leucaena (Leucaena leucocephala hibrida dan Leucaena leucocephala lokal) pada tiga aras (0, 25 dan 50\%). Penelitian dilakukan menggunakan rancangan acak lengkap. Tepung hijauan murbei, leucaena dan campuran hijauan murbei-leucaena diinkubasi dalam gelas syringe selama 24 jam. Parameter yang diamati adalah produksi gas, kecernaan sejati in vitro bahan kering (IVTDMD), kecernaan $\mathrm{N}$ in vitro (IVND), dan produksi VFA. Hasil penelitian menunjukan bahwa suplementasi hijauan leucaena pada hijauan murbei menurunkan produksi gas, kecernaan bahan organik, dan kecernaan protein dalam rumen buffer. Campuran hijaun murbei dengan leucaena hibrida pada rasio 50\% menghasilkan kecernaan protein terendah dalam rumen buffer dibandingkan dengan perlakuan yang lain. Namun demikian terjadi peningkatan kecernaan protein dalam pepsin $\mathrm{HCl}$ yang merupakan indikator prakiraan kecernaan protein dalam usus. Total produksi gas terjadi penurunan pada campuran hijauan murbei leucana yang diikuti dengan penurunan produksi total VFA. Suplementasi leucaena hibrida pada murbei dengan rasio 1 : 1 paling efektif untuk menurunkan kecernaan protein ruminal dan meningkatkan kecernaan protein yang diinkubasi pada pepsin $\mathrm{HCl}$. Dapat disimpulkan bahwa pencampuran leucaena hybrid mampu memproteksi degradasi protein murbei di dalam rumen.
\end{abstract}

Kata Kunci: Murbei, Leucaena, Kecernaan Protein, In Vitro

\begin{abstract}
Yulistiani D, Jelan ZA, Liang JB. 2016. In Vitro protein digestibility and fermentability of mulberry (Morus alba)-Leucaena foliage mixed feed. JITV 21(1): 9-18. DOI: http://dx.doi.org/10.14334/jitv.v21i1.1352

This experiment was carried out to determine the effect of mulberry-leucaena foliage mixed feed on protein digestibility and VFA production using an in vitro gas production study. Mulberry was mixed with one of 2 leucaena varieties (Leucaena leucocephala hybrid and Leucaena leucocephala local) at 3 levels (0, 25 and 50\%). Study was conducted in completely randomized design. Mulberry foliage, leucaena and mixtures of mulberry-leucaena were incubated for 24 hours in glass syringes. Parameter recorded were gas production, in vitro true dry matter digestibility (IVTDMD), in vitro N digestibility (IVND) and VFA production. Results of the study showed that supplementation of leucaena to mulberry decreased IVOMD, gas production and protein digestibility in the rumen buffered medium. The mixture of mulberry and leucaena hybrid at ratio $50 \%$ resulted in the lowest IVND than other treatment. However it increased protein digestibility in acid pepsin incubation as an estimate of protein availability in intestine. Gas production decreased in mulberry leucaena mixtures was followed by decreased total VFA production. Tannin derived from leucaena hybrid supplementation to mulberry at ratio $1: 1$ was most effective to decrease protein digestion in the rumen and to increase protein digestibility in acid pepsin incubation. In conclusion mixing of hybrid leucaena hybrid with mulberry foliage was able to protect protein degradation from mulberry in the rumen.
\end{abstract}

Key Words: Mulberry, Leucaena, Protein Digestibility, In Vitro

\section{INTRODUCTION}

The key of successful and sustainable ruminant farming in tropical conditions is dependent on the attempt to formulate reliable cheap feeding strategy based on resource availability. This is due to the scarcity and fluctuation in quantity and quality of year round supply of conventional feeds. The situation is exacerbated by the increase human population and decrease land availability for forage crop production that cause ruminants feeding depends on crop residue and agricultural by products with "low nutritional quality". One of the methods to maximize the utilization of fibrous agricultural residues is by supplementing essential nutrients in the basal feed to correct the nutrients imbalances. Several 
supplementation strategies have been developed using commercial concentrate, this supplementation could improve crop residues digestibility, intake and animal performance. However, although the above method is effective, the using of concentrate by small farmers is limited by cost particularly when it is imported. The high cost of imported concentrate led to seeking for alternative locally available forages for ruminants feed. This effort has practical implication because it is easy to adopt by small scale farmers. Tree foliages, shrubs and agro-industrial by-products are important in animal production in the tropics because they do not compete with human food and can provide significant protein supplements (Makkar 2003). Recently, there is increasing interest on the use Mulberry as ruminants feed due to its biomass production potency, palatability and nutritive value. Supplementation of pelleted mulberry leaves was able to improve rumen fermentation and nutrient digestibility of cattle fed on rice straw basal diet (Huyen et al. 2012), recently Yulistiani et al. (2015) also reported that in urea treated rice straw basal diet, mulberry supplementation can replace urea and rice bran as energy and protein sources. However, protein degradability of mulberry was very high. After 24 hours incubation, the protein of mulberry was degraded more than $80 \%$ in the rumen regardless of dietary treatments of the sheep (Yulistiani et al. 2008). Gemeda \& Hassen (2015) also reported that, in vitro incubation of mulberry (Morus alba) produced highest $\mathrm{NH}_{3} \mathrm{~N}$ among the tropical browse plants from South Africa, indicating that protein in mulberry was highly degradable in the rumen resulting in the loss of valuable essential amino acid sources for host animals.

There are many methods to reduce protein feed degradability in the rumen Saddul et al. (2004) reported that heating of mulberry foliage could reduce its protein degradability. Compared to other treatments, Protein protection using tannin is better and give positive response, Getachew et al. (2008) reported addition of quebraco tannin or tannin acid ranges from 5-15\% reduced in vitro rumen degradability of protein in alfalfa forage.

Leucaena, one of leguminous trees can be used as tannin source to protect protein degradability of soy bean meal (Cortés et al. 2009). Hybrid Leucaena developed in Malaysia has been reported to have high content of condensed tannin (13\%) (Khamseekhiew 2006) and moderate amount (2.0-4.5\% DM) of condensed tannin has a beneficial effect on protein metabolism in ruminants and give better nutritional value of tree fodder species (Camacho et al. 2010). Condensed tannin decreased rumen degradation of dietary protein and increased absorption of amino acids in the small intestine (Barry \& McNabb 1999). The mixture of mulberry, Leucaena and Tectona grandis leaves could result in increase rumen escape protein (Anbarasu et al. 2004), which can be utilized by the host animals. The objectives of this study were to evaluate the digestibility and protein degradability in mixture of Leucaena and mulberry by in vitro gas production technique and to determine the best ratio of Leucaena to mulberry in reducing protein degradation in the rumen.

\section{MATERIALS AND METHODS}

\section{Feed}

\section{Mulberry foliage}

Mulberry grown at the experimental plot of the Department of Animal Science, Universiti Putra Malaysia, Serdang, Selangor, Malaysia, was harvested after about 5-7 weeks re-growth. Foliage was air-dried under shed for 3 days, chopped then ground using hammer mill and passed through a $1 \mathrm{~mm}$ sieve.

\section{Leucaena foliage}

The foliage was harvested at 8 weeks of re-growth (from previous cutting), oven-dried at $45^{\circ} \mathrm{C}$ for 2 days, chopped, ground using hammer mill and passed through a $1 \mathrm{~mm}$ sieve. Leucaena leucocephala local variety and Leucaena leucocephala hybrid variety contained condensed tannin (CT) 9.6 and $13.1 \%$ respectively (Khamseekhiew 2006), while mulberry foliage contained CT $0.16 \%$ (Saddul 2005).

\section{Preparation of diets}

Mulberry foliage was mixed with each of two varieties of Leucaena (hybrid or local) at 2 levels: $25 \%$ and $50 \%$ on DM basis as shown in Table 1 and the nutrient composisition of the diets presented in Table 2 .

\section{In vitro $\mathrm{OM}$ digestibility}

A 24 hours gas production test was carried out to determine truly degradable fermented substrates (in vitro true dry matter degradability/IVTDMD). In this incubation, $500 \mathrm{mg}$ sample was incubated in $40 \mathrm{ml}$ of medium. The medium was prepared according to (Makkar et al. 1997). Each diets treatment was incubated in 4 syringes as replication. Gas volume was recorded at 2, 4, 6, 8, 10 and $24 \mathrm{~h}$ incubation. After terminating the incubation, five $\mathrm{ml}$ of supernatant from each syringes was taken for volatile fatty acid (VFA) analysis, prior the residue in the syringe was transferred into a $600 \mathrm{ml}$ spoutless beaker. The syringe was washed with a total of $70 \mathrm{ml}$ of NDS solution. The procedure of 
Yulistiani et al. In Vitro protein digestibility and fermentability of mulberry (Morus alba)-Leucaena foliage mixed feed

Table 1. List of experimental diets

\begin{tabular}{lcccc}
\hline \hline \multirow{2}{*}{ Type of diet } & \multicolumn{3}{c}{ Ratio (\%) } & Calculated CT content of \\
mixed feed (\%)
\end{tabular}

LL: Leucaena leucocephala local variety; LH: Leucaena leucocephala hybrid variety; M: Mulberry

Table 2. Nutrient composisition of experimental feeds

\begin{tabular}{llllll}
\hline \hline \multirow{2}{*}{ Feed ingredients } & \multicolumn{5}{c}{ Chemical composition (\% DM) } \\
\cline { 2 - 6 } & DM & OM & CP & NDF & ADF \\
\hline Mulberry & 92.2 & 91.7 & 18.9 & 41.5 & 25.4 \\
Leucaena leucocephala hybrid (LH) & 93.6 & 95.7 & 21.5 & 45.1 & 28.3 \\
Leucaena leucocephala local (LL) & 93.0 & 95.1 & 21.3 & 44.5 & 29.0 \\
M/LH (1:1) & 92.3 & 93.7 & 20.2 & 43.3 & 26.8 \\
M/LL (1:1) & 92.6 & 93.4 & 20.1 & 43.0 & 27.2 \\
M/LH (3:1) & 93.1 & 74.1 & 25.4 & 38.2 & 19.0 \\
M/LL (3:1) & 92.4 & 92.5 & 19.5 & 42.2 & 26.3 \\
\hline
\end{tabular}

M/LH (1: 1): mulberry and Leucaena leucocephala hybrid mixture at ratio $50: 50 \%$

M/LH $(3: 1)$ : mulberry and Leucaena leucocephala hybrid mixture at ratio $75: 25 \%$

M/LL (1:1): mulberry and Leucaena leucocephala local mixture at ratio $50: 50 \%$

M/LL (3 : 1): mulberry and Leucaena leucocephala local mixture at ratio $75: 25 \%$

(Van Soest et al. 1991) was then applied by refluxing the incubation residue for $1.0 \mathrm{~h}$ and filtering the undigested matter on pre-tared filter crucibles. True digested of dry matter was calculated as the weight of substrate incubated minus the weight of the residue after NDS treatment. Rumen fluid was obtained from rumen-cannulated cattle maintained on roughage concentrate diet at the ratio of $60: 40 \mathrm{DM}$.

\section{Determination of in vitro $\mathrm{N}$ digestibility}

Determination of in vitro $\mathrm{N}$ digestibility (IVND) was conducted on the samples using a modified Tilley \& Terry (1963) two-stage digestion method (Palmer \& Jones 2000). $0.5 \mathrm{~g} \mathrm{DM}$ of each sample was weighed into calibrated glass syringes, followed by addition of $40 \mathrm{ml}$ of rumen fluid: buffer $(1: 4)$. There were 2 sets of 4 replicates of each treatment together with four blanks in separate tubes that received no sample were incubated. The syringes were incubated in water bath at $39^{\circ} \mathrm{C}$ for $24 \mathrm{~h}$. Then the content of the syringes was centrifuged for $20 \mathrm{~min}$ at $2500 \mathrm{~g}$. Supernatant of $3 \mathrm{ml}$ was taken for VFA analysis. The remaining supernatant was decanted and $40 \mathrm{ml}$ of distilled water was added. The suspension was thoroughly mixed using a vortex mixer and then centrifuged again for $20 \mathrm{~min}$, the supernatant again discarded, and the process repeated 3 times. Each tube from one set of 4 replicates then added with $40 \mathrm{ml}$ of acid pepsin ( $2 \mathrm{~g}$ of $1: 10,000$ pepsin in 11 of $0.1 \mathrm{M} \mathrm{HCl}$ ), thoroughly mixed then incubated at $39^{\circ} \mathrm{C}$ for $24 \mathrm{~h}$. After incubation, the mixture was centrifuged for $20 \mathrm{~min}$, the supernatant discarded, and the residue dried at $65^{\circ} \mathrm{C}$ for $48 \mathrm{~h}$ prior to weighing. Another one set of 4 replicates after being centrifuged was oven dried at $65^{\circ} \mathrm{C}$ for $48 \mathrm{~h}$ prior to weighing. The calculation of IVND in the rumen medium (X) 


$$
X=\frac{A-(B-D)}{A} \times 100
$$

Whereas calculation of total IVND (Y) was:

$$
Y=\frac{A-(C-D)}{A} \times 100
$$

$\mathrm{A}=\mathrm{N}$ in sample before incubated

$\mathrm{B}=\mathrm{N}$ in residue after samples incubated in the rumen buffered medium

$\mathrm{C}=\mathrm{N}$ residue after samples incubated in acid pepsin solution

$\mathrm{D}=\mathrm{N}$ residue of the blank after incubation

$$
\mathrm{P}=\frac{\mathrm{R}}{\mathrm{A}} \times 100
$$

Where:

$\mathrm{P}=$ The IVND in the acid pepsin

$\mathrm{R}=$ total IVND $(\mathrm{X})$ - IVND in the rumen $(\mathrm{Y})$

The predicted $\mathrm{N}$ digestibility was also calculated from the incubation of individual feeds which then extrapolated, this calculation was done to see the synergistic effect of mulberry and leucaena mixture.

\section{Chemical analyses}

The feed samples were analyzed for DM, OM and $\mathrm{CP}$ according to the procedures of AOAC (2000). ADF and NDF were determined using the method of Van Soest et al. (1991).

The volatile fatty acid (VFA) and molar proportions of acetic, propionic and butyric acids of supernatant from incubated samples were determined by gas chromatography (Model G1540N, Agilent Technologies, USA) fitted with a flame ionization detector (FID) and a packed column 5\% Thermon-3000, Shincarbon A 60/80. Nitrogen was used as the carrier gas at $40 \mathrm{ml} / \mathrm{min}$ and the oven temperature was maintained at $220^{\circ} \mathrm{C}$. Injection and FID temperature were fixed at $260^{\circ} \mathrm{C}$.

\section{Statistical analysis}

The experiment was carried out in a completely randomized design and data were analysed using Anova of SAS package version 9.1 (2002). Means were compared by Duncan's multiple range test.

\section{RESULT AND DISCUSSION}

\section{Result}

The effect of Leucaena mixed with mulberry on gas production, IVDMD and amount of substrate fermented is shown in Table 3. Gas production and true organic matter digestibility were significantly $(\mathrm{P}<0.05)$ lower in mulberry mixed with Leucaena than mulberry alone. However, the the amount drry matter being fermented was not significantly decreased when mulberry was mixed with hybrid Leucaena at 50\% level. Hybrid Leucaena had significantly $(\mathrm{P}<0.05)$ higher gas production, digestibility and amount of substrate fermented than the local variety of Leucaena.

Table 4 shows the effect of mulberry mixed with Leucaena on protein digestibility in rumen buffer media, acid pepsin solution and total protein digestibility. Protein degradation in the buffered rumen media was significantly decreased in mixture of mulberry and Leucaena compared to mulberry alone. The decrease of protein degradation was highest in mulberry mixed with $50 \%$ hybrid Leucaena M/LH $(1: 1)$. The decrease of protein degradation in rumen buffered media caused the increased protein degradation in the acid pepsin incubation. The M/LH $(1: 1)$ mixture had the highest protein digestion in acid pepsin. However, other mixtures, their protein digestion was significantly lower M/LH $(3: 1)$ and M/LL $(3: 1)$ or similar M/LL (1:1) to Leucaena. Total protein digestibility was significantly $(\mathrm{P}<0.05)$ decreased in mulberry mixed Leucaena at all supplementation levels. The total protein digestibility of M/LH $(3: 1)$ and M/LL (3:1) was comparable to both Leucaena hybrid and local. The protein digestibility of M/LH (1:1) and M/LL (1:1) were comparable but they were higher than M/LH (3:1) and M/LL (3:1) mixture.

Figure 1 shows the measured and predicted value of protein digestibility in the rumen from different mixture of mulberry and Leucaena at different level. The predicted values were calculated from the incubation of individual feeds which then extrapolated. It shows that the measured value in protein degradation of mulberry and Leucaena mixture in buffered rumen media was lower than the predicted value. The highest difference between measured and predicted protein degradation was observed at M/LH $(3: 1)(42 \%)$.

Figure 2 shows the measured and predicted values of protein digestibility in acid pepsin from the mixture of mulberry and Leucaena. It shows that the measured of protein digestibility was higher than the predicted values. The highest difference between measured and predicted values was in the M/LH (3:1) $(65 \%)$.

The effect of Leucaena mixed with mulberry on VFA production is shown in Table 5. The mixture of mulberry and Leucaena significantly decreased total VFA compared to mulberry alone. However, the total VFA production was not significantly different between the mixture with different Leucaena varieties and ratios. Total VFA production of all mixtures was not significantly different to Leucaena variety alone except for $\mathrm{M} / \mathrm{LL}(1: 1)$ mixture. 
Yulistiani et al. In Vitro protein digestibility and fermentability of mulberry (Morus alba)-Leucaena foliage mixed feed

There were no significant differences in the proportion of butyric acid among treatments. The exception was in the M/LH $(3: 1)$ mixture which had significantly higher value than the hybrid Leucaena. Mulberry had significantly higher proportion of iso valeric acid than other diets except for M/LH (3:1).
However, the proportion of iso valeric acid of M/LH (3 : 1) was only significantly different to hybrid Leucaena. The proportion of Acetic acid, propionic acid and iso butyric acid was comparable $(\mathrm{P}>0.05)$ among treatments.

Table 3. Estimates of in vitro true dry matter digestibility (IVTDMD), fermentable substrate, volume gas production derived from 24 hours in vitro fermentation of $500 \mathrm{mg}$ DM of the experimental diets

\begin{tabular}{lccc}
\hline \hline Treatment & Gas production $(\mathrm{ml})$ & IVTDMD $(\%)$ & Substrate fermented (DM, mg) \\
\hline Mulberry (M) & $85.7^{\mathrm{a}}$ & $80.5^{\mathrm{a}}$ & $402.7^{\mathrm{a}}$ \\
Leucaena Hybrid (LH) & $59.5^{\mathrm{e}}$ & $75.8^{\mathrm{b}}$ & $378.9^{\mathrm{b}}$ \\
Leucaena Local (LL) & $55.8^{\mathrm{f}}$ & $67.3^{\mathrm{c}}$ & $336.4^{\mathrm{c}}$ \\
M/LH $(1: 1)$ & $74.3^{\mathrm{c}}$ & $77.5^{\mathrm{ab}}$ & $387.4^{\mathrm{ab}}$ \\
M/LH (3:1) & $67.6^{\mathrm{d}}$ & $68.8^{\mathrm{c}}$ & $344.0^{\mathrm{c}}$ \\
M/LL (1:1) & $76.9^{\mathrm{b}}$ & $73.7^{\mathrm{b}}$ & $368.3^{\mathrm{b}}$ \\
M/LL (3:1) & $75.6 \mathrm{~b}^{\mathrm{c}}$ & $73.6^{\mathrm{b}}$ & $368.2^{\mathrm{b}}$ \\
S.E.M. & 0.78 & 1.46 & 0.23 \\
\hline
\end{tabular}

Means with different superscript in the same column are significantly different $(\mathrm{P}<0.05)$

S.E.M.: standard error means

M/LH (1:1): mulberry and Leucaena leucocephala hybrid mixture at ratio $50: 50 \%$

M/LH (3: 1): mulberry and Leucaena leucocephala hybrid mixture at ratio $75: 25 \%$

M/LL (1: 1): mulberry and Leucaena leucocephala local mixture at ratio $50: 50 \%$

M/LL (3:1): mulberry and Leucaena leucocephala local mixture at ratio $75: 25 \%$

Table 4. Estimates apparent protein digestibility of mulberry, Leucaena and mixed mulberry and Leucaena after incubation for 24 hours in rumen buffer media followed by acid pepsin digestion

\begin{tabular}{lccc}
\hline \hline Treatment & $\begin{array}{c}\text { Microbial protein digestion } \\
(\%)\end{array}$ & $\begin{array}{c}\text { Acid pepsin digestion } \\
(\%)\end{array}$ & $\begin{array}{c}\text { Total protein } \\
\text { digestion }\end{array}$ \\
\hline Mulberry (M) & $83.7^{\mathrm{a}}$ & $7.6^{\mathrm{d}}$ & $91.3^{\mathrm{a}}$ \\
Leucaena Hybrid (LH) & $13.6^{\mathrm{d}}$ & $55.9^{\mathrm{b}}$ & $69.4^{\mathrm{c}}$ \\
Leucaena Local (LL) & $15.7^{\mathrm{cd}}$ & $53.6^{\mathrm{b}}$ & $69.4^{\mathrm{c}}$ \\
M/LH $(1: 1)$ & $13.6^{\mathrm{d}}$ & $60.2^{\mathrm{a}}$ & $73.8^{\mathrm{b}}$ \\
M/LH $(3: 1)$ & $18.8^{\mathrm{bc}}$ & $48.8^{\mathrm{c}}$ & $67.6^{\mathrm{c}}$ \\
M/LL $(1: 1)$ & $21.0^{\mathrm{b}}$ & $55.4^{\mathrm{b}}$ & $76.4^{\mathrm{b}}$ \\
M/LL $(3: 1)$ & $21.7^{\mathrm{b}}$ & $46.5^{\mathrm{c}}$ & $68.2^{\mathrm{c}}$ \\
S.E.M. it is better to put std for each value. & 1.37 & 0.86 & 0.93 \\
\hline
\end{tabular}

Means with different superscript in the same column are significantly different $(\mathrm{P}<0.05)$

S.E.M. = standard error means

M/LH $(1: 1)=$ mulberry and Leucaena leucocephala hybrid mixture at ratio $50: 50 \%$

M/LH $(3: 1)=$ mulberry and Leucaena leucocephala hybrid mixture at ratio $75: 25 \%$

$\mathrm{M} / \mathrm{LL}(1: 1)=$ mulberry and Leucaena leucocephala local mixture at ratio $50: 50 \%$

$\mathrm{M} / \mathrm{LL}(3: 1)=$ mulberry and Leucaena leucocephala local mixture at ratio $75: 25 \%$ 


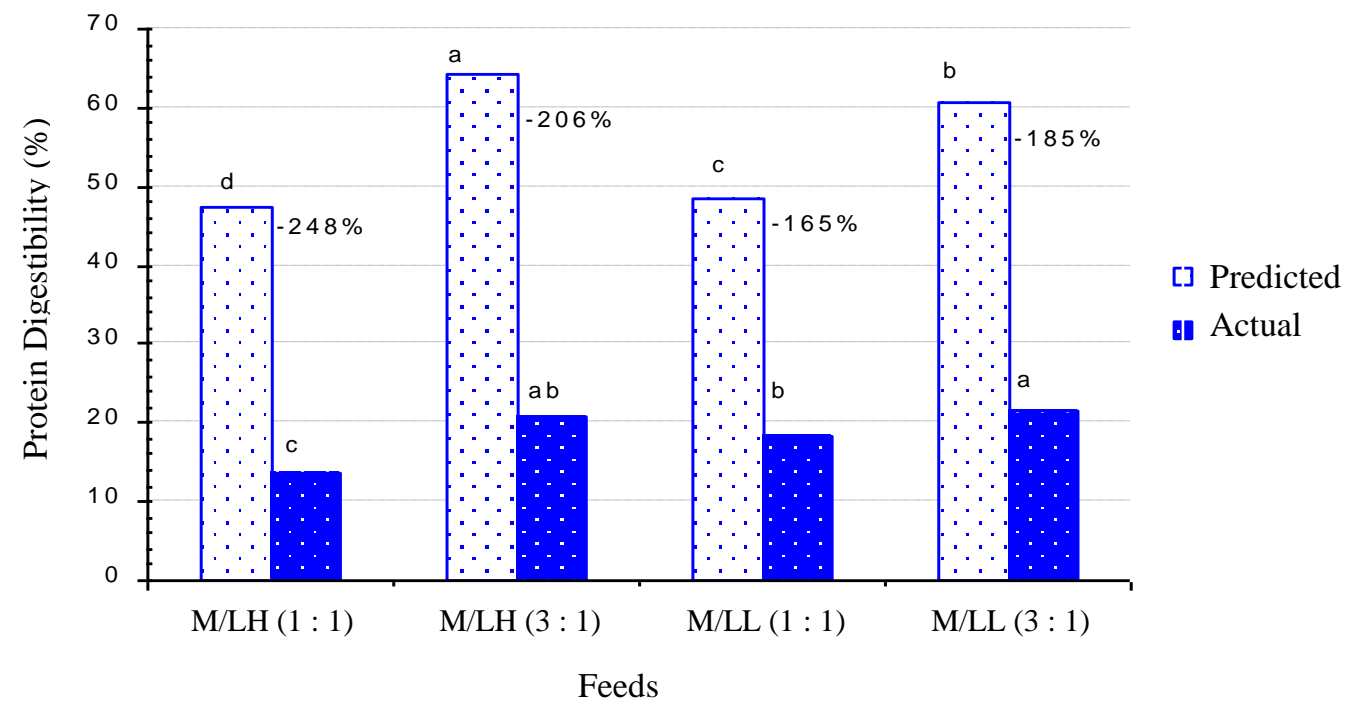

Figure 1. Protein degradability in rumen buffered media extrapolated from incubation of individual feed and measured by incubation of two feeds in different combination M/LH (1:1): mulberry and Leucaena leucocephala hybrid mixture at ratio $50: 50 \%$; M/LH (3: 1): mulberry and Leucaena leucocephala hybrid mixture at ratio $75: 25 \% ; \mathrm{M} / \mathrm{LL}(1: 1)$ : mulberry and Leucaena leucocephala local mixture at ratio $50: 50 \% ; \mathrm{M} / \mathrm{LL}(3: 1)$ : mulberry and Leucaena leucocephala local mixture at ratio 75 : $25 \%)$.

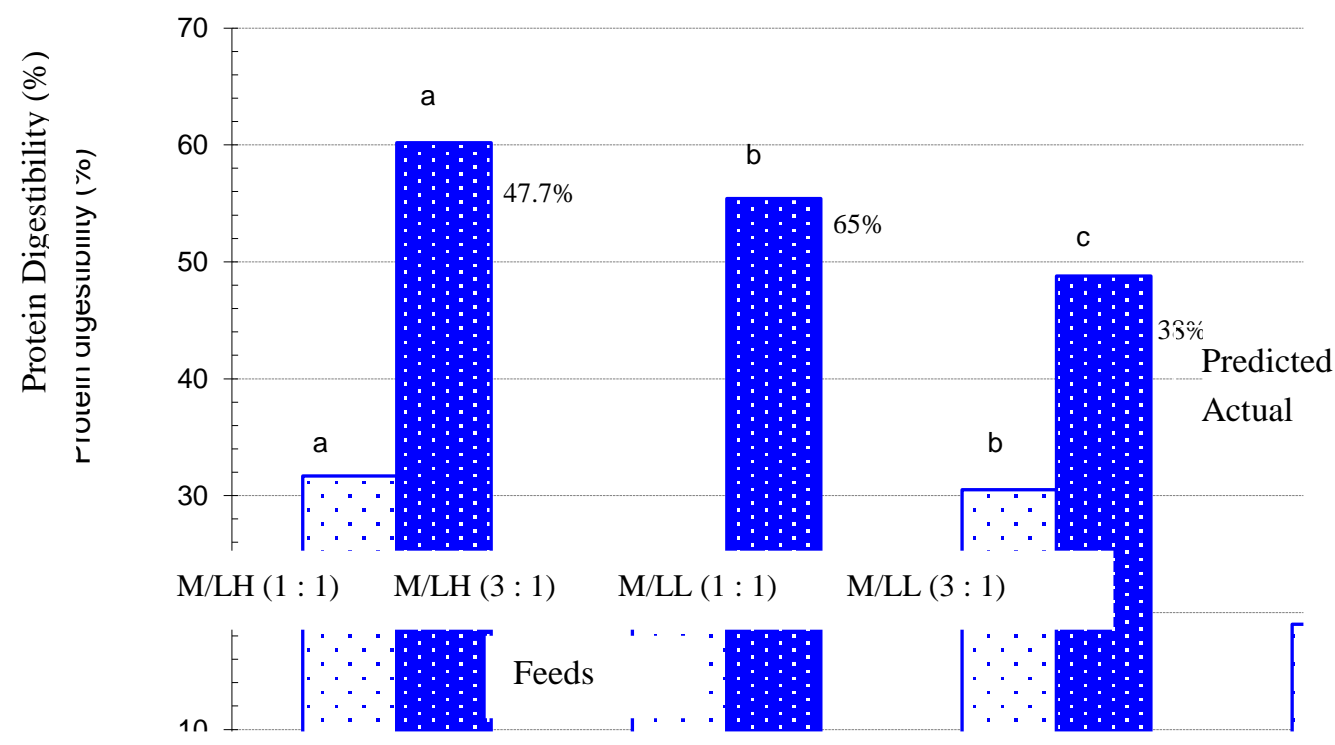

Figure 2. Protein digestibility in acid pepsin solution media extrapolated from incubation of individual feed and measured by incubation of two feeds in different combination M/LH $(1: 1)$ : mulberry and Leucaena leucocephala hybrid mixture at ratio $50: 50 \%$; M/LH (3:1): mulberry and Leucaena leucocephala hybrid mixture at ratio $75: 25 \%$; M/LL (1 : 1): mulberry and Leucaena leucocephala local mixture at ratio $50: 50 \%$; M/LL (3:1): mulberry and Leucaena leucocephala local mixture at ratio $75: 25 \%$. 


\section{Discussion}

\section{In vitro digestibility}

There is a good agreement between the magnitude of IVTOMD to the corresponding gas production. The high the IVTOMD value the higher is the gas production (Makkar 2003). However, in this study though gas production of mulberry was reduced when it was mixed with leucaena, but in mixture mulberry leucaena hybrid 50\% (M/LH= $1: 1)$ its IVTOMD was not significantly decreased (Table 3). Moreover, in Leucaena hybrid, though its gas production was significantly lower than other diets treatment, its IVTOMD was comparable to other diets except for mulberry. This indicates that the levels of tannin presented in the mixture diets did not limit the fermentability of the feeds. Getachew et al. (2000) and Guerrero et al. (2012) also reported that despite the lower gas production of tanniferous browses, its true digestibility was not affected by the presence of tannin. Similarly Norrapoke et al. (2014) also observed in rice straw diet supplemented by plant containing condensed tannin and saponin (mangosteen powder) did not reduce feed digestibility but decreased gas production. This condition was caused by the leaching of tannins from feed during fermentation, contributing to the DM loss but without contributing to the gas production or inhibition of cell soluble (Getachew et al. 1998; Makkar et al. 1997).

Table 5. Total VFA production and proportion of VFA of mulberry, Leucaena and their mixture after $24 \mathrm{~h}$ incubation

\begin{tabular}{|c|c|c|c|c|c|c|c|}
\hline \multirow{2}{*}{ Treatment } & \multirow{2}{*}{$\begin{array}{l}\text { Total VFA } \\
(\mathrm{mM})\end{array}$} & \multicolumn{6}{|c|}{ Proportion of VFA $(\%)$} \\
\hline & & $\mathrm{C} 2$ & C3 & $\mathrm{C} 4$ & $\mathrm{C} 5$ & $\mathrm{C} 4 \mathrm{i}$ & $\mathrm{C} 5 \mathrm{i}$ \\
\hline Mulberry (M) & $87.8^{\mathrm{a}}$ & 66.6 & 22.3 & $7.11^{\mathrm{ab}}$ & $1.23^{\mathrm{d}}$ & 1.04 & $1.92^{\mathrm{a}}$ \\
\hline Leucaena Hybrid (LH) & $48.6^{c}$ & 67.0 & 22.7 & $6.24^{b}$ & $1.34^{\mathrm{cd}}$ & 0.95 & $1.12^{\mathrm{c}}$ \\
\hline Leucaena Local (LL) & $37.3^{c}$ & 67.0 & 22.0 & $6.47^{\mathrm{ab}}$ & $2.20^{\mathrm{a}}$ & 0.90 & $1.39^{\mathrm{bc}}$ \\
\hline M/LH (1: 1) & $58.3^{\mathrm{bc}}$ & 67.5 & 21.3 & $7.14^{\mathrm{ab}}$ & $1.59^{\mathrm{bcd}}$ & 0.97 & $1.51^{\mathrm{b}}$ \\
\hline M/LH (3: 1) & $47.6^{\mathrm{bc}}$ & 65.6 & 22.1 & $7.64^{\mathrm{a}}$ & $1.75^{\mathrm{bc}}$ & 1.15 & $1.74^{\mathrm{ab}}$ \\
\hline M/LL (1: 1) & $66.6^{b}$ & 66.6 & 21.7 & $7.23^{\mathrm{ab}}$ & $1.84^{\mathrm{ab}}$ & 1.03 & $1.55^{\mathrm{b}}$ \\
\hline M/LL (3 : 1) & $51.0^{\mathrm{bc}}$ & 68.2 & 20.9 & $7.03^{\mathrm{ab}}$ & $1.49^{b c d}$ & 0.93 & $1.40^{\mathrm{bc}}$ \\
\hline S.E.M. & 6.76 & 2.11 & 0.66 & 0.44 & 0.15 & 0.1 & 0.13 \\
\hline
\end{tabular}

Means with different superscript in the same column are significantly different $(\mathrm{P}<0.05)$

S.E.M. = standard error means;

$\mathrm{C} 2 \quad=$ acetic acid

$\mathrm{C} 3=$ propionic acid

$\mathrm{C} 4 \mathrm{i}=$ iso butyric acid

$\mathrm{C} 4 \quad$ = butyric acid

C5i = iso valeric acid

C5 = valeric acid

M/LH(1:1): mulberry and Leucaena leucocephala hybrid mixture at ratio $50: 50 \%$

M/LH (3:1): mulberry and Leucaena leucocephala hybrid mixture at ratio $75: 25 \%$

M/LL (1: 1): mulberry and Leucaena leucocephala local mixture at ratio $50: 50 \%$

M/LL (3: 1): mulberry and Leucaena leucocephala local mixture at ratio $75: 25 \%$
Further more, condensed tannin in the feed have more pronounced effect on protein degradability (Tiemann et al. 2008). However, Huang et al. (2010) reported that addition of various levels (2-5\%) purified tannin from leucaena hybrid which was similar leucaena variety used in the current study to Panicum maximum grass substrate was able to reduce both in vitro DMD and total gas production, but the extent of reduction in gas production was higher than in digestibility. The gas decline by $19.68 \%$ when tannin was added at $2 \%$ and further decline to maximum $33.63 \%$ when the tannin dition was increased into $4 \%$ DM In this study the levels of tannin addition (based on tannin content of leucaena) was higher $(6.45 \%$ and $3.13 \%$ at leucaena hybrid mixture at $50 \%$ and $25 \%$ respectively reduction of gas production was lower $(13.3 \%$ and respectively for mixture at 50 and $25 \%$ ) the Huang et al. (2010) might be caused by the difference nnin activity in extracted form (Huang et al. 2010) in the plant materials form such in the current study. Naumann et al. (2015) also reported that different level of tannin content and different source in the diet did not affect total gas production. fermentation varied. Different tannin from different eedstuff have different inhibitory effect on rumen microbial activity which in turn affect on feed fermentation (Singh et al. 2005; Tiemann et al. 2008). the current study with previous study reported by 


\section{In vitro $\mathrm{N}$ digestibility}

The mixture of mulberry with $50 \%$ hybrid Leucaena resulted in the lowest IVND than other treatments. When the level of the Leucaena decreased, the $\mathrm{N}$ degradability was increased by $50 \%$, indicating that the level of tannin content in Leucaena affect the $\mathrm{N}$ degradability in the rumen (Table 4). Huang et al. (2010) reported addition of $2 \%$ purified tannin from Leucaea hybrid reduce degradability by $17.65 \%$ of protein Panicum maximum grass, further increased of tannin addition up to $4 \%$ did not resulted in further decreased of the protein substrate. Anti nutritional effect of tannin is exerted through reduction of feed protein digestion and a depression of proteolytic enzyme activities (Jones et al. 1994). A reduction in crude protein degradability is the consequence of condensed tannin (CT) binding to dietary constituents and to bacteria. In addition, the $\mathrm{CT}$ can reduce attachment of bacteria to plant particle (McAllister et al. 1994). Getachew et al. (2000) reported that IVDN increased when PEG (tannin binding agent) was added to the tannin-rich browse. The increase of the extent of $\mathrm{N}$ digestibility by rumen microbial due to PEG addition indicates the amount of protein protected by tannin from microbial degradation. In the present study, the protein degradability of mulberry-Leucaena mixture was reduced compared to mulberry alone. The decrease of protein degradability could be due to the effect of tannin from Leucaena. Previously Williams et al. (2011) reported that total mixed ration of sainfonin hay based-diet contained $3.8 \%$ tannin, rumen ammonia nitrogen content of the diet was lower compared to alfalfa hay based-diet with low tannin content $(0.2 \%)$, the lower rumen ammonia nitrogen as indication of protein protection by tannin in the rumen. The in vitro protein degradability in M/LH (1:1) mulberyLeucaena mixture was lower than other mixtures (Table 3). It shows that hybrid Leucaena has higher effect in decreasing protein degradability than Leucaena local (M/LL). The Leucaena varieties used in this study was similar tree reported by Khamseekhiew (2006) and Huang et al. (2010). Khamseekhiew (2006) reported that hybrid Leucaena had higher CT content than Leucaena local, which caused the lower $\mathrm{N}$ degradability in the former. In addition, CT in hybrid Leucaena had stronger binding affinity than Leucaena local (Huang et al. 2010). The CT which have stronger affinity and have higher molecular weight have higher ptotein binding affinity than those with lower molecular weight (Saminathan et al. 2004). Similar results was also reported by (Kariuki \& Norton 2008) that within Leucaena genus has different ability in protecting protein. Moreover (Cortés et al. 2009) also observed that effect of tannin in protecting protein beside affected by source of tannin also by ratio of tannin added.
The protein degradability of mulberry alone was higher, however when it was mixed with leucaena the protein degradability was reduced though the protein content of this mixture was higher than mulberry (Table 2 ). The measured protein degradability was lower than the predicted value, indicating that there was an associative effect between mulberry and leucaena when it was incubated together. According Getachew et al. (2005) combination of different feed ingredients incubated together with condition that one feed is not independent to other feed will results in associative effect which can be detected when the response of the combination is not linear. This associative effect caused by the presence of feed ingredients stimulate rumen fermentation and consequently its affect the digestibility of other feed ingredients. Through the positive associative effect, the present study shows that protein digestibility in acid pepsin was higher in the measured values than in the predicted value. Protein availability for digestion in the intestines (acid pepsin) increased from only $8 \%$ in mulberry to $82 \%$ in $\mathrm{M} / \mathrm{LH}(1: 1)$ mulberry-Leucaena mixture rate. Although the total protein digestibility decreased from $91.3 \%$ in mulberry to $73.8 \%$ in $\mathrm{M} / \mathrm{LH}(1: 1)$ or $76.4 \%$ in M/LL $(1: 1)$, the protein digestion was available for the absorption in the intestine. The acid pepsin digestible protein could be regarded as a potential rumen by pass protein. McSweeney et al. (1999) reported that in browse (Lucerne) containing no tannin, accumulation of $\mathrm{NH}_{3}-\mathrm{N}$ has strong correlation with $\mathrm{N}$ degradation. On the other hand, in tannin containing shrub legumes had lower potential $\mathrm{N}$ digestibilities in the rumen. However, a large portion is available following the acid pepsin digestion compared to Lucerne, this was due to protein tannin complex would be dissociated post-ruminally. McLeod (1974) as referred by Norton \& Ahn (1997) observed that tannin bind protein in the rumen at $\mathrm{pH}$ 5.8-6.8 and the linkages are strongly dependent on $\mathrm{pH}$. The linkage being stable at $\mathrm{pH} 3.5-7.0$, but this tanninprotein complexes should be dissociated in the abomasum ( $\mathrm{pH} 2.5-3.5)$ and in small intestine $(\mathrm{pH} 7.5-$ 8.5 ). Therefore protecting protein from digestion in the rumen is the advantage of the presence protein-tannin complex in the diet thereby increasing total supply of feed protein for absorption (Makkar 2003).

\section{VFA production}

The higher total VFA production in mulberry than other diets (Table 5) was a results from the high IVTDMD of mulberry (Table 3 ) this due to VFA is one of the products beside gases and microbial cell from carbohydrates fermentation. Mixing leucaena to mulberry resulted in the decreased of total VFA production. The decrease of total VFA was also reflected in lower IVTDMD and gas production of 
mulberry-leucaena mixed diets (Table 3). The decrease of fermentability these diets could be caused by the present of tannin from leucaena. Tannin decrease attachment of fibre digesting microbes to feed particles (McAllister et al. 1994) therefore decrease rate of digestion which in turn decreased VFA production. This is consistent with the previous study that showed the tannin content in tree browse reduced the gas and total VFA production (Getachew et al. 2002; (Khamseekhiew 2006). However, the molar proportion of acetic and propionic, and iso butyric acid was not affected by treatment. On the other hand, the molar proportion of iso-valeric in mulberry-leucaena mixed diet was significantly decreased compared to mulberry. The decreased of iso-valeric which mostly from deamination of some amino acid (Copani et al. 2015) in mixed mulberry leucaena suggest that protein of mulberry was protected by condensed tannin from leucaena. Simlar result was also reported by Copani et al. (2015) in mixture of Timothy grass and Sainfonin, and by Niderkorn et al. (2012) in mixture of cocksfood and sainfonin.

\section{CONCLUSION}

Supplementation of Leucaena to mulberry decreased in vitro true dry matter digestibility (IVDMD) and decreased protein digestibility in the buffered rumen fluid media. Leucaena supplementation could increase protein digestibility in acid pepsin incubation as indicator of protein availability in intestine. Hybrid Leucaena supplementation to mulberry at ratio $1: 1$ was the most effective level to decrease protein digestion in the rumen and to increase protein digestibility in acid pepsin incubation.

\section{REFERENCES}

[AOAC] Association of Official Analytical Chemist. 2000. Official method of analysis. 17th ed. Washington DC (USA): Association of Official Analytical Chemist.

Anbarasu C, Dutta N, Sharma K, Rawat M. 2004. Response of goats to partial replacement of dietary protein by a leaf meal mixture containing Leucaena leucocephala, Morus alba and Tectona grandis. Small Rumin Res. 51:47-56.

Barry TN, McNabb WC. 1999. The implications of condensed tannins on the nutritive value of temperate forages fed to ruminants. Br J Nutr. 81:263-272.

Camacho LM, Rojo R, Salem AZM, Mendoza GD, López D, Tinoco JL, Albarrán B, Montãnez-Valdez OD. 2010. In vitro ruminal fermentation kinetics and energy utilization of three Mexican tree fodder species during the rainy and dry period. Anim Feed Sci Technol. 160:110-120.
Copani G, Ginane C, Le Morvan A, Niderkorn V. 2015. Patterns of in vitro rumen fermentation of silage mixtures including sainfoin and red clover as bioactive legumes. Anim Feed Sci Technol. 208:220-224.

Cortés JE, Moreno B, Pabón ML, Avila P, Kreuzer M, Hesse HD, Carulla JE. 2009. Effects of purified condensed tanins extracted from Calliandra, Flemingia and Leucaena on ruminal and postruminal degradation of soybean meal as estimated in vitro. Anim Feed Sci Technol. 151:194-204.

Gemeda BS, Hassen A. 2015. Effect of tannin and species variation on In vitro digestibility, gas, and methane production of tropical browse plants. Asian-Australas J Anim Sci. 28:188-199.

Getachew G, Blummel M, Makkar HPS, Becker K. 1998. In vitro gas measuring techniques for assessment of nutritional quality of feeds: a review. Anim Feed Sci Technol. 72:261-281.

Getachew G, DePeters EJ, Robinson PH, Fadel JG. 2005. Use of an in vitro rumen gas production technique to evaluate microbial fermentation of ruminant feeds and its impact on fermentation products. Anim Feed Sci Technol. 123-124:547-559.

Getachew G, Makkar HPS, Becker K. 2000. Effect of polyethylene glycol on in vitro degradability of nitrogen and microbial protein synthesis from tannin-rich browse and herbaceous legumes. Br J Nutr. 84:73-83.

Getachew G, Makkar HPS, Becker K. 2002. Tropical browses: contents of phenolic compound and stoichiometric relationship between short chain fatty acid and in vitro gas production. J Agr Sci Camb. 139:341-352.

Getachew G, Pittroff W, Putnam DH, Dandekar A, Goyal S, DePeters EJ. 2008. The influence of addition of gallic acid, tannic acid, or quebracho tannins to alfalfa hay on in vitro rumen fermentation and microbial protein synthesis. Anim Feed Sci Technol. 140:444-461.

Guerrero M, Cerrillo-Soto MA, Ramírez RG, Salem AZM, González H, Juárez-Reyes AS. 2012. Influence of polyethylene glycol on in vitro gas production profiles and microbial protein synthesis of some shrub species. Anim Feed Sci Technol. 176:32-39.

Huang XD, Liang JB, Tan HY, Yahya R, Khamseekhiew B, Ho YW. 2010. Molecular weight and protein binding affinity of Leucaena condensed tannins and their effects on in vitro fermentation parameters. Anim Feed Sci Technol. 159:81-87.

Huyen NT, Wanapat M, Navanukraw C. 2012. Effect of Mulberry leaf pellet (MUP) supplementation on rumen fermentation and nutrient digestibility in beef cattle fed on rice straw-based diets. Anim Feed Sci Technol. 175:8-15.

Jones GA, McAllister TA, Mair AD, Cheng KJ. 1994. Effect of sainfonin (Onobrychis viciaefolia Scop) condensed tannin on growth and proteolysis by four strains of ruminal bacteria. Appl Env Microbiol. 60:1374-1378. 
Kariuki IW, Norton BW. 2008. The digestion of dietary protein bound by condensed tannins in the gastrointestinal tract of sheep. Anim Feed Sci Technol. 142:197-209.

Khamseekhiew B. 2006. Characteristics and protein binding affinity of condensed tannins in leucaena species (Thesis). [Malaysia (Malaysia)]: University Putra Malaysia.

Makkar HPS. 2003. Effects and fate of tannin in ruminant animals, adaptation to tannins, and strategies to overcome detrimental effects of feeding tannin-rich feeds: Review. Small Rumin Res. 49:241-256.

Makkar HPS, Blummel M, Becker K. 1997. In vitro rumen apparent and true digestibilities of tannin-rich forages. Anim Feed Sci Technol. 67:245-251.

McAllister TA, Bae HD, Jones GA, Cheng KJ. 1994. Microbial attachment and feed digestion in the rumen. $\mathrm{J}$ Anim Sci. 72:3004-3018.

McSweeney CS, Palmer B, Bunch R, Krause DO. 1999. In vitro quality assessment of tannin-containing tropical shrub legumes: protein and fibre digestion. Anim Feed Sci Technol. 82:227-241.

Naumann HD, Lambert BD, Armstrong SA, Fonseca MA, Tedeschi LO, Muir JP. 2015. Effect of replacing alfalfa with panicled-tick clover or sericea lespedeza in cornalfalfa-based substrates on in vitro ruminal methane production. J Dairy Sci. 98:3980-3987.

Niderkorn V, Mueller-Harvey I, Le Morvan A, Aufrère J. 2012. Synergistic effects of mixing cocksfoot and sainfoin on in vitro rumen fermentation Roleof condensed tannins. Anim Feed Sci Technol. 178:48-56.

Norrapoke T, Wanapat M, Foiklang S. 2014. Influence of tropical plant sources containing plant secondary compound on rumen fermentation using in vitro gas fermentation technique. Indian J Anim Sci. 84:10041010 .

Norton BW, Ahn JH. 1997. A comparison of fresh and dried Calliandra calothyrsus supplements for sheep given a basal diet of barley straw. J Agr Sci Camb. 129:485494.

Palmer B, Jones RJ. 2000. The effect of PEG addition on dry matter and nitrogen digestibility of Calliandra calothyrsus and Leucaena leucocephala leaf. Anim Feed Sci Technol. 85:259-268.
Saddul D. 2005. Evaluation and utilization of Morus alba (mulberry) as a protein supplement for ruminants (Thesis). [Malaysia (Malaysia)]: University Putra Malaysia.

Saddul D, Jelan ZA, Liang JB, Halim RA. 2004. Effect of high drying temperatures on protein fraction and in vitro gas production mulberry foliage. In: New Dimens Challenges Sustain Livest Farming Vol III Proceeding 11th Anim Sci Congr Asian-Australasian Assoc Anim Prod Soc. Kuala Lumpur (Malaysia): Malaysian Society of Animal Production. p. 402-404.

Saminathan M, Tan HY, Sieo CC, Abdullah N, Wong CMVL, Abdulmalek E, Ho YW. 2004. Polymerization degrees, molecular weights and protein-binding affinities of condensed tannin fractions from a Leucaena leucocephala hybrid. Molecules. 19:7990-8010.

Singh B, Sahoo B, Sharma R, Bhat TK. 2005. Effect of polyethylene glycol on gas production parameters and nitrogen disappearance of some tree forages. Anim Feed Sci Technol. 123-124:351-364.

Van Soest PJ, Robertson JB, Lewis BA. 1991. Methods for dietary fiber, neutral detergent fiber and non-starch polysaccharides in relation to animal nutrition. J Dairy Sci. 74:3583-3593.

Tiemann TT, Avila P, Ram'irez G, Lascano CE, Kreuzer M, Hess HD. 2008. In vitro ruminal fermentation of tanniniferous tropical plants: Plant-specific tannin effects and counteracting efficiency of PEG. Anim Feed Sci Technol. 146:222-241.

Tilley JM, Terry RA. 1963. A two-stage technique for the in vitro digestion of forage crops. Br J Nutr. 18:104-111.

Williams CM, Eun JS, MacAdam JW, Young AJ, Fellner V, Min BR. 2011. Effects of forage legumes containing condensed tannins on methane and ammonia production in continuous cultures of mixed ruminal microorganisms. Anim Feed Sci Technol. 166-167:364372.

Yulistiani D, Jelan ZA, Liang JB. 2008. Degradability of mulberry (Morus alba) and rice bran in the rumen of sheep fed different diets. Indones J Anim Vet Sci. 13:264-272.

Yulistiani D, Jelan ZA, Liang JB, Yaakub H, Abdullah N. 2015. Effects of supplementation of mulberry (Morus $a l b a$ ) foliage and urea-rice bran as fermentable energy and protein sources in sheep fed urea-treated rice straw based diet. Asian Australas J Anim Sci. 28:494-501. 